\title{
Students' and faculty members' perceptions of the importance of business ethics and accounting ethics education: Iranian case
}

\author{
Ramazanali Royaee • Saied Ali Ahmadi • Azam Jari
}

Received: 6 July 2012 / Accepted: 25 September 2012 / Published online: 11 October 2012

(C) Springer Science+Business Media Dordrecht 2012

\begin{abstract}
The aim of this research is to investigate students' and faculty members' perceptions of the importance of business ethics and accounting ethics education. The study uses a survey instrument to elicit student and faculty responses to various questions concerning the importance of business ethics and accounting ethics education. The sample consists of 75 faculty members and 108 accounting Master students and multiple regression models were used for analyzing and testing hypotheses. The results indicate that there is no significant relationship between dependant variables, the importance of ethics and the importance of goals of ethics education, and independent variables such as responder group, gender, age, and experience. In the other words, independent variables do not create perceptual gap on the importance of ethics and the importance of the goals of ethics education in accounting between faculty members and students. Also, statistical analyses indicate that students and faculty members consider both business ethics and the goals of accounting ethics education.
\end{abstract}

Keywords Ethics $\cdot$ Perceptual gap $\cdot$ Accounting ethics education

\section{Introduction}

Nowadays, with improvement of capital markets in all countries and clarification of their importance in collecting and handling small capitals of investors, the need for

\footnotetext{
R. Royaee $\cdot$ S. A. Ahmadi $(\bowtie)$

Department of Accounting, Science and Research Branch, Islamic Azad University (IAU),

Tehran, Iran

e-mail: saeidaliahmadi@yahoo.com

R. Royaee

e-mail: Culturalmanagment@srbiau.ac.ir

A. Jari

Department of Accounting, Mobarakeh Branch, Islamic Azad University (IAU), Isfahan, Iran e-mail: azam_jari@yahoo.com.au
} 
accounting and auditing services in taking economical decisions is inevitable (Valipour et al. 2012). Accounting has a main role in providing information for users of financial statement. Accounting information should have special features to be used in the decision making process. According to the Financial Accounting Standards Board, one of the goals on preparing financial statements is providing information for investors and creditors and other users for their investment decisions (Ansuj et al. 1996). Whereas users of financial statements rely on issued information and take their decisions, they attend to auditors' perception about being fair on financial statements in their decisions; so the nature of accountants' and auditors' activities need to have a high level of ethics. Ethics can help accountants and auditors to conquest on ethical conflicts in the workplace (Massey et al. 2006). The corporate accountability of an organization is frequently disputed within the disciplines of finance and business ethics. Specifically, stockholder and stakeholder theories represent different views of this ethical debate (Merphy and Josephine 2011). Nevertheless, individuals disregard recent organizational scandals in their responsibilities and acted only in their own ignoring both the stockholders and the stakeholders. Organizational scandals have resulted in loss of public trust as well as increased government regulation on publicly held companies. Examples of this increased regulation include the Sarbanes-Oxley Act (2002) and the related Public Company Accounting Oversight Board. Also, education, similar to government regulation, has also been used in an attempt to control ethical lapses. In fact, Cohen et a.1 (1998) argued that government regulation could not completely ensure ethical behavior; there is a need for business ethics education. This need for business ethics education is a recurring theme within the academic environment. So that, in 1986, the American Institute of Certified Public Accountant members agreed to create new changes in laws; these changes made the faculty members want to teach ethics in the accounting course. The American Accounting Association issued a report about accounting education content and the importance of business ethics in accounting. The report expresses that professional education must be must not only be focused on skill and knowledge but also on ethical principles and commitments in the accounting profession. These problems indicate that if an ethical lesson exists in accounting, it will cause ethical decisions (Mintz 1998).

In this study, we investigate whether perceptions of the importance of business ethics and accounting ethics education between students and faculty members are different or not. This article has been built upon the research of Adkins and Radtek (2004) by matching faculty members' and students' perceptions using the same instrument. It extends recent research on the business ethics education in Asian countries. Students' and faculty members' perceptions of the importance of business ethics and accounting ethics education in Asian countries are considered less than other countries and so it needs to be more explored in Asian countries.

This study is motivated by the two major considerations. First, the difference of this research with prior research is in using independent variables as experience. This variable has not been investigated in prior research. Second, in this paper, the Master students are used in the research sample.

The remainder of the paper has been organized as follows. The "Literature review" section presents the prior research for the paper while the "Research hypotheses" section describes the research hypotheses. The "Research methodology" section describes the research methodology and the "Research sample" section presents the 
research sample. The "Results" section present results and finally the "Conclusion" section presents the conclusions of the study.

\section{Literature review}

In this section, we investigate some research which study about faculty members' and students' perceptions about the importance of business ethics and accounting ethics education.

Merphy and Josephine (2011) investigated faculty members' and students' perceptions of business ethics education by using faculty members' and students' perceptions. This study has been conducted in Tennessee and Michigan which examined faculty members' perceptions of the effectiveness, importance, and faculty members' responsibility of business ethics education. The results indicate that faculty members and students have different perceptions of business ethics education in two areas. Specifically, faculty members perceive there is more importance placed on teaching business ethics than students and faculty members perceive that they have a greater responsibility to teach business ethics than students. In addition, further analysis shows that faculty and students have different views of business ethics education.

Adkins and Radtek (2004) investigated faculty members' and students' perceptions about the importance of business ethics and accounting ethics education. They examined whether accounting students' perceptions of business ethics and the goal of accounting ethics education are fundamentally different from accounting faculty members' perceptions. Researchers used questionnaire for data collection and multiple regression models for investigating impact independent variables such as age, gender, responder group, and being Caucasian on dependant variables including ethics and the goals of ethics education in accounting. The results indicate that students consider both business ethics and the goals of accounting ethics education to be more important than faculty members. Also, research findings show that women will perceive ethics in accounting education to be more important than men. But the results show that older subjects does not perceive ethics in accounting education to be more important than younger subjects and that Caucasian subjects do not perceive ethics in accounting education to be more important than subjects of other ethnicities.

Kerr and Smith (1995) investigated accounting students' perceptions about the methods of ethics participation in accounting course. Their results show students believe that ethics is a main subject in business and accounting profession miscarries without ethics.

Stevens et al. (1993) compared ethical evaluations of faculty members and students. One hundred thirty-seven students (45 first year students and 67 last year students) and 34 faculty members participated in this research. The results show that there is meaningful difference in seven of 30 positions between first year students and faculty members and in four of 30 positions between last year students and faculty members. Also, the findings indicate that there was no difference between faculty members and students when average of the groups were measured.

Ricklets (1983) confirms that there is meaningful difference between women and men in ethics judgments in his research. The results show that women are more 
ethical than men. Cohen et al. (1998) investigated the impact gender on ethical evaluations and ethical intention in accountants' employment. Their results show that women know doubtful actions to be more non-ethical than men.

In some researches, such as of Borkowski and Ugras (1992) and Ruegger and King (1992), it has been shown that older subjects use ethics in their decisions to be more important than younger subjects because subjects informed of ethical matters are more older, so they can take ethical decisions.

Fischer and Rosenzweig (1995) investigated students' and accountants' perceptions about being ethical of earning management. The results show that students are idealistic because they do not have experience and when they achieve experience, they will be realistic. Overall, the research results indicate that there are perceptual gap between faculty members and students about the importance of business ethics and accounting ethics education in the USA and UK.

\section{Research hypotheses}

The based on research literature, the research hypotheses expressed as follow:

$\mathrm{H}_{1}$ : Faculty members will perceive ethics in accounting education to be more important than students.

$\mathrm{H}_{2}$ : Women will perceive ethics in accounting education to be more important than men.

$\mathrm{H}_{3}$ : Older subjects will perceive ethics in accounting education to be more important than younger subjects

$\mathrm{H}_{4}$ : Experienced subject will perceive ethics in accounting education to be more important than wit out experienced subjects.

\section{Research methodology}

This research is structured as a survey research. We used multiple regression model for testing research hypotheses and questionnaire for data collection. In other words, for testing hypotheses, a method that has two processes was used. In the first process, the questionnaire (including 14 questions) was codified. It was adapted base on the research of Adkins and Radtek (2004). We divided the questions to four groups. In the first group, information about independent variables such as gender, age, experience, and responder groups were collected. We propounded questions about the importance of ethics in four general areas including the business community, business course, personal decisions, and decisions in the workplace in the second group. In the third group, the importance of goals of accounting ethics education was questioned. In this group, seven questions are adapted base on researches such as Callahan (1980), Loeb (1988), Geary and Sims (1994), and Adkins and Radtek (2004). In the second and third questions, a seven-point Likert scale has been used. We investigated existence and lack of an ethics lesson in accounting with three questions in the forth group. For investigating validity of questionnaire, faculty members' opinions were used and their opinions were exerted in the questionnaire. Cronbach's 
alpha coefficient was used for reliability assaying. After validity of reformations was done, 60 questionnaires as primary test were issued between faculty members and Master accounting students. The result of Cronbach's alpha determined 87 and $88 \%$ for faculty members and Master students.

\section{Research sample}

The research sample includes Master accounting students and faculty members. Research questionnaire (its validity and reliability has been confirmed) was used to determine research sample. In other words, we used 60 questionnaires that were issued between faculty members and students. Calculations indicate that standard deviation for faculty members and Master students' responses is 44 and $53 \%$. After standard deviation was determined, the following formula was used for calculating of research sample:

$$
n=\left(\frac{Z_{\frac{\alpha}{2}} \times \sigma}{\varepsilon}\right)^{2}
$$

Where:

$$
\begin{array}{ll}
\alpha & \text { error level } \\
\sigma & \text { standard deviation } \\
\varepsilon & \text { accuracy }
\end{array}
$$

In this study, with $5 \%$ error level, $10 \%$ accuracy, 44 and $53 \%$ standard deviation for faculty members and Master students, the numbers of faculty members and Master students (75 and 108, respectively) were determined.

\section{Results}

The multiple regression models were used for investigating impact-independent variables (gender, age, experience, and responder groups) on dependent variables. The results of testing hypotheses have been shown in Table 1.

As $T$ test shows independent variables are not meaningful in $5 \%$ level, so zero hypothesis of these variables is not rejected. In other words, the importance of ethics between faculty members with students, women with men, older subjects with younger subjects, subjects without experience with experienced subjects in four areas, the business community, business course, personal decision, and decision in the workplace do not have meaningful differences. The results of this study for impact-independent variables including responder group, experience, and gender is inconsistent with prior research such as Adkins and Radtek (2004), Cohen et al. (1998), and Fischer and Rosenzweig (1995); but for impact-independent variable such as age, it is consistent with the research of Fischer and Rosenzweig (1995).

The results of four hypotheses about the important of goals of ethics education in accounting have been shown in Table 2. $T$ test is not meaningful 
Table $1 T$ tests on sample responses between students and faculty for concept questions (concerning the importance of ethics)

\begin{tabular}{llllll}
\hline Concept questions & Responder group & Gender & Age & Experience & Adjusted $R^{2}$ \\
\hline $\begin{array}{l}\text { How important is ethics } \\
\text { in the business }\end{array}$ & $-0.113(-0.468)$ & $-0.204(-0.851)$ & $\begin{array}{l}0.015 \\
(0.853)\end{array}$ & $-0.046(-0.222)$ & 0.008 \\
$\quad \begin{array}{llll}\text { community? } \\
\text { How important is ethics }\end{array}$ & $0.003(0.013)$ & $0.052(0.225)$ & 0.016 & $-0.038(-0.192)$ & 0.008 \\
in business courses? & & & $(0.931)$ & \\
$\begin{array}{l}\text { How important is ethics } \\
\text { in your personal }\end{array}$ & $-0.25(-1.406)$ & $-0.015(-0.086)$ & 0.003 & $-0.077(-0.502)$ & 0.018 \\
decisions? & & & $(0.208)$ & & \\
$\begin{array}{l}\text { How important is ethics } \\
\text { in your decisions }\end{array}$ & $0.126(0.638)$ & $-0.217(-1.113)$ & 0.007 & $-0.099(-0.585)$ & 0.014 \\
in the workplace? & & & $(0.515)$ & & \\
\hline
\end{tabular}

$Q R=\alpha+\beta_{1}$ group $+\beta_{2}$ gender $+\beta_{3}$ age $+\beta_{4}$ experience $+\varepsilon$

The numbers in parentheses show $T$ test

for all independents variables in $5 \%$ level. So, zero hypothesis of these variables is not rejected. In other words, the importance of goals of ethics education does not have meaningful difference based on independent variables (responder groups, gender, age, and experience). Also, the research results are inconsistent with prior researches (Adkins and Radtek 2004; Cohen et al. 1998; Fischer and Rosenzweig 1995).

The results of the questions about existence or lack of an ethical lesson in accounting course have been shown in Table 3. Based on Mann-Whitney test, there is no meaningful difference in $5 \%$ level between responder groups of faculty members and students. Also, more students answered "yes" to questions. So, faculty members and Master students think that having an ethics course in college would help them solve moral and ethical issues facing the accounting profession and the business community in general. The results of this research are consistent with Adkins and Radtek (2004).

\section{Conclusion}

In this study, we investigated students' and faculty members' perceptions of the importance of business ethics and accounting ethics education. Recent scandals in accounting and auditing need to be more focused on ethical principles. It is necessary that we investigate students' and faculty members' perceptions about the importance of business and accounting ethics education before an ethical lesson can be created in the accounting course.

In this study, for investigating the importance ethics in four general areas and ethical education in accounting, four and seven questions were used. The research instrument is the questionnaire. For investigating the impactindependent variables such as responder group, gender, age, and experience 
Table $2 T$ tests on sample responses between students and faculty for goals questions concerning (the importance of accounting ethics education)

\begin{tabular}{|c|c|c|c|c|c|}
\hline Concept questions & Responder group & Gender & Age & Experience & Adjusted $R^{2}$ \\
\hline $\begin{array}{l}\text { Relate accounting } \\
\text { education to } \\
\text { moral issues }\end{array}$ & $0.087(0.385)$ & $-0.165(-0.735)$ & $\begin{array}{c}0.014 \\
(0.868)\end{array}$ & $0.017(0.089)$ & 0.011 \\
\hline $\begin{array}{l}\text { Recognize issues } \\
\text { in accounting that } \\
\text { have ethical } \\
\text { implications }\end{array}$ & $0.252(1.121)$ & $-0.22(-0.984)$ & $\begin{array}{l}-0.005 \\
(-0.323)\end{array}$ & $-0.129(-0.665)$ & 0.014 \\
\hline $\begin{array}{l}\text { Develop a "sense } \\
\text { of moral obligation" } \\
\text { or responsibility }\end{array}$ & $0.289(1.64)$ & $-0.354(-1.021)$ & $\begin{array}{c}-0.01 \\
(-0.805)\end{array}$ & $0.25(1.645)$ & 0.042 \\
\hline $\begin{array}{l}\text { Develop the abilities } \\
\text { needed to deal with } \\
\text { ethical conflicts or } \\
\text { dilemmas }\end{array}$ & $0.229(1.121)$ & $-0.331(-1.634)$ & $\begin{array}{l}-0.005 \\
(-0.354)\end{array}$ & $0.114(0.649)$ & 0.02 \\
\hline $\begin{array}{l}\text { Learn to deal with } \\
\text { the uncertainties of } \\
\text { the accounting } \\
\text { profession }\end{array}$ & $0.173(0.711)$ & $-0.298(-1.232)$ & $\begin{array}{r}0.008 \\
(0.436)\end{array}$ & $0.346(1.646)$ & 0.027 \\
\hline $\begin{array}{l}\text { "Set the stage for" } \\
\text { a change in ethical } \\
\text { behavior }\end{array}$ & $0.16(0.758)$ & $-0.344(-1.646)$ & $\begin{array}{r}0.012 \\
(0.802)\end{array}$ & $0.169(0.93)$ & 0.028 \\
\hline $\begin{array}{l}\text { Appreciate and } \\
\text { understand the } \\
\text { history and } \\
\text { composition of } \\
\text { all aspects of } \\
\text { accounting ethics } \\
\text { and their } \\
\text { relationship to the } \\
\text { general field } \\
\text { of ethics }\end{array}$ & $0.169(0.64)$ & $-0.109(0.78)$ & $\begin{array}{c}0.015 \\
(0.58)\end{array}$ & $0.132(-0.416)$ & 0.016 \\
\hline
\end{tabular}

$Q R=\alpha+\beta_{1}$ group $+\beta_{2}$ gender $+\beta_{3}$ age $+\beta_{4}$ experience $+\varepsilon$

The numbers in parentheses show $T$ Test

on dependent variables, multiple regression was used to assess the importance of ethics in four general areas and the importance of goals ethics education in accounting.

The results indicate that there is no significant relationship between dependent variables, the importance of ethics and the importance of goals of ethics education, and independent variables such as responder group, gender, age, and experience. In the other words, independent variables do not create conceptual gap about the importance of ethics and the importance of goals ethics education in accounting between faculty members and students. Also, statistical analyses indicate that students and faculty members consider both business ethics and the goals of accounting ethics education. 
Table 3 The results of questions about existence or lack an ethical lesson in accounting course

\begin{tabular}{|c|c|c|c|c|}
\hline \multirow[t]{2}{*}{ Concept questions } & \multirow[t]{2}{*}{ Group } & \multicolumn{2}{|c|}{ Response (\%) } & \multirow[t]{2}{*}{ Mann-Whitney test } \\
\hline & & Yes & No & \\
\hline \multirow{2}{*}{$\begin{array}{l}\text { If an ethics course in business were offered as an } \\
\text { elective, would you enroll in it? }\end{array}$} & Students & 68 & 32 & \multirow[t]{2}{*}{$4.08(0.60)$} \\
\hline & Faculty & 64 & 36 & \\
\hline \multirow{2}{*}{$\begin{array}{l}\text { Do you believe it is appropriate to have business } \\
\text { faculty teach an ethics course? }\end{array}$} & Students & 72 & 28 & \multirow[t]{2}{*}{$3.75(0.07)$} \\
\hline & Faculty & 84 & 16 & \\
\hline \multirow{2}{*}{$\begin{array}{l}\text { Do you think that having an ethics course in college } \\
\text { would help you (your students) solve moral and } \\
\text { ethics issues facing the accounting profession and } \\
121 \text { the business community in general? }\end{array}$} & Students & 66 & 34 & \multirow[t]{2}{*}{$4.23(0.98)$} \\
\hline & Faculty & 67 & 33 & \\
\hline
\end{tabular}

The numbers of parentheses show $P$ value

On the basis of the results, we recommend increasing the importance of accounting ethics and decreasing the ethical conflictions in workplaces in Iran; additionally, business ethics and accounting ethics subjects should be present in universities in Iran. This study contributes to the empirical evidence on the importance of business ethics and accounting ethics education in Asian countries.

\section{References}

Adkins, N., \& Radtek, R. R. (2004). Students' and faculty members' perceptions of the importance of business ethics and accounting ethics education: is there an expectations gap? Journal of Business Ethics, 51, 279-300.

Ansuj, A., Camargo, M., Radharamanan, R., \& Petry, D. (1996). Sales forecasting using TimeSeries and neural networks. International Journal of Forecasting, 31(1-2), 421-424.

Borkowski, S., \& Ugras, Y. (1992). The ethical attitudes of students as a function of age, sex and experience. Journal of Business Ethics, 11, 961-979.

Callahan, D. (1980). Goals in the teaching of ethics. In D. Callahan \& S. Bok (Eds.), Ethics teaching in higher education (pp. 61-80). New York: Plenum Press.

Cohen, J., Pant, L., \& Sharp, D. (1998). The effect of gender and academic discipline diversity on the ethical evaluations, ethical intentions and ethical orientation of potential public accounting recruits. Accounting Horizons, 12, 250-270.

Fischer, M., \& Rosenzweig, K. (1995). Attitudes of students and accounting practitioners concerning the ethical acceptability of earnings management. Journal of Business Ethics, 14, 433-444.

Geary, W., \& Sims, R. (1994). Can ethics be learned? Accounting Education, 3, 3-18.

Kerr, D., \& Smith, L. (1995). Importance of and approaches to incorporating ethics into the accounting classroom. Journal of Business Ethics, 14, 987-998.

Loeb, S. (1988). Teaching students accounting ethics: some crucial issues. Issues in Accounting Education, 3, 316-329.

Massey, D., Wand, L., \& Thorne. (2006). The impact of task information feedback on ethical reasoning. Behavioral Research in Accounting, 18, 103.

Merphy E. Josephine (2011). Faculty and student perceptions of business ethics education at an undergraduate institution. Dissertation presented in partial fulfillment of the requirements for the degree Doctor of Philosophy.

Mintz, S. M. (1998). Cases in accounting ethics and professionalism. New York: McGraw-Hill. 
Ricklets, R. (1983) Executives and general public say ethical behavior is declining in U.S. Wall Street Journal (October 31), 33.

Ruegger, D., \& King, E. (1992). A study of the effect of age and gender upon student business ethics. Journal of Business Ethics, 11, 179-186.

Stevens, R., Harris, O., \& Williamson, S. (1993). A comparison of ethical evaluations of busines school faculty and students: a pilot study. Journal of Business Ethics, 12, 611-619.

Valipour, H., Salehi, M., \& Rostami, V. (2012). The effects of experience and education on perceiving the importance of ethical factors and commitment to code of professional conduct - case of Iran's accounting society. American Journal of Scientific Research, 52, 78-87. 